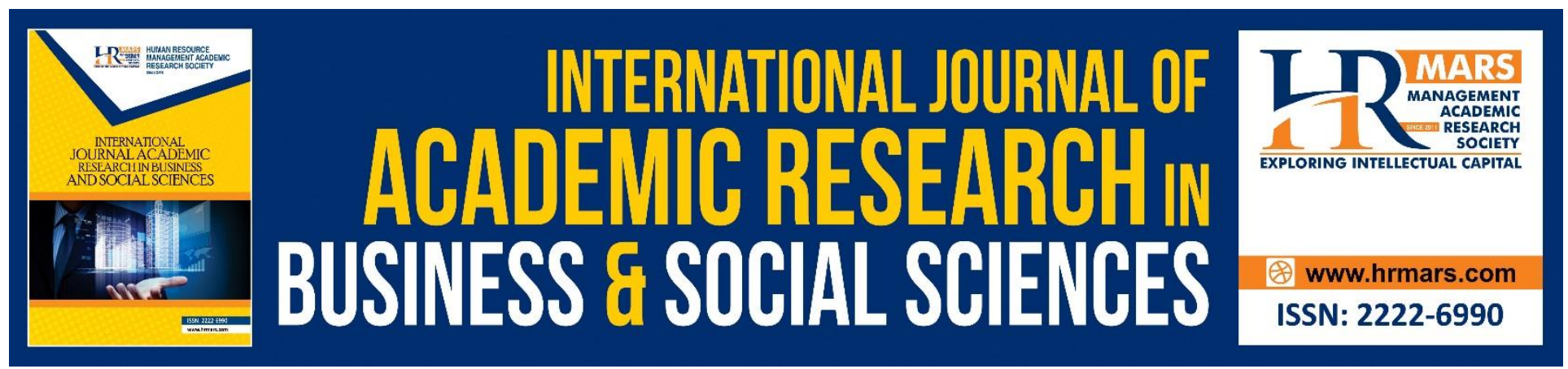

\title{
Applications of Interpretive Structural Modeling for Walking Digital Gallery Physical Education and Health Model
}

\section{Nik Hazira Ghazali, Saedah Siraj, Syed Kamaruzaman Syed Ali, Kasful Asra}

To Link this Article: http://dx.doi.org/10.6007/IJARBSS/v10-i7/7594

DOI:10.6007/IJARBSS/v10-i7/7594

Received: 07 May 2020, Revised: 02 June 2020, Accepted: 14 June 2020

Published Online: 28 July 2020

In-Text Citation: (Ghazali et al., 2020)

To Cite this Article: Ghazali, N. H., Siraj, S., Ali, S. K. S., \& Asra, K. (2020). Applications of Interpretive Structural Modeling for Walking Digital Gallery Physical Education and Health Model. International Journal of Academic Research in Business and Social Sciences, 10(7), 660-670.

Copyright: (C) 2020 The Author(s)

Published by Human Resource Management Academic Research Society (www.hrmars.com)

This article is published under the Creative Commons Attribution (CC BY 4.0) license. Anyone may reproduce, distribute, translate and create derivative works of this article (for both commercial and non-commercial purposes), subject to full attribution to the original publication and authors. The full terms of this license may be seen

at: http://creativecommons.org/licences/by/4.0/legalcode

Vol. 10, No. 7, 2020, Pg. 660 - 670

http://hrmars.com/index.php/pages/detail/IJARBSS

JOURNAL HOMEPAGE

Full Terms \& Conditions of access and use can be found at http://hrmars.com/index.php/pages/detail/publication-ethics 


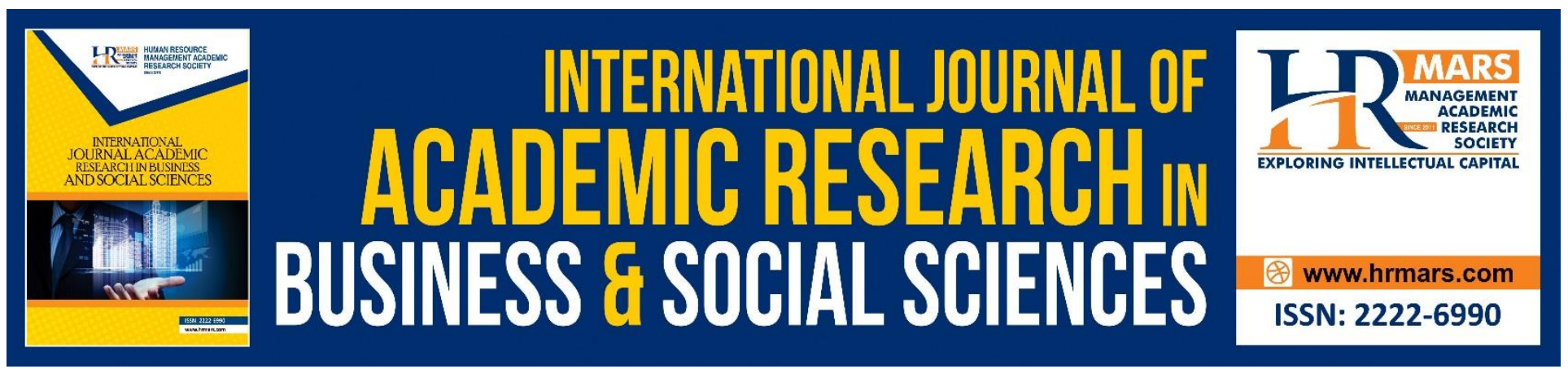

\title{
Applications of Interpretive Structural Modeling for Walking Digital Gallery Physical Education and Health Model
}

\author{
Nik Hazira Ghazali, Saedah Siraj, Syed Kamaruzaman Syed Ali, \\ Kasful Asra \\ Universiti Malaya, Fakulti Pendidikan, Universiti Malaya, 50603, Kuala Lumpur \\ Email: zie1011@hotmail.com, saedah@um.edu.my, syedkamaruzaman@gmail.com, \\ kasful@um.edu.my
}

\begin{abstract}
This paper presents the development of Walking Digital Gallery for Physical Education and Health primary's school subjects. The study adopted the Interpretive Structural Modeling (ISM) method to develop the model that can be use by teachers. 8 panel of experts was choosen in this research to complete the ISM procedure. Findings from phase 2 have produced a model element consisting of 21 elements of teaching. All these elements are related to each other to form a model of teaching implementation. The panel of experts also agreed that the activities in the model can be divided into 4 stations and clusters to facilitate the interpretation of the role of each of these elements and this is in accordance with the concept of the Walking Digital Gallery Physical Education and Health model. Keywords: Model, Interpretive Structural Modeling, Physical Education and Health subject, Walking Digital Gallery
\end{abstract}

\section{Introduction}

According to Veloo \& Ali (2016), Physical Education and Health (PEH) has been a key subject since 1989. The PEH subject is also a compulsory subject as it aims to create a healthy, active and productive future generation. The subject also emphasizes the knowledge and skills aspects of the experience gained through the $\mathrm{PEH}$ indirectly enabling students to adopt a healthy culture and lifestyle.

In addressing the PEH curriculum, the Circular Letter from the Office of the Director General of Education Malaysia number 5/1998 stated that Physical Education subjects are core subjects and should be implemented as provided for in the Education Act 1996 (Ali et.al, 2014). And, to meet the national aspirations, the Physical Education and Health Education (PEH) subjects in schools also underwent many changes in line with the current educational development and needs. In 2003, PEH subjects in primary and secondary schools have undergone revision of the curriculum with emphasis on knowledge, skills and self-esteem to prepare for current and future challenges. Teaching and 
learning need to be enhanced to be more effective in meeting the needs of the students, parents and nation. This revised curriculum emphasizes the content of the curriculum text and the more effective delivery method (BPPM PJK, 2019)

The education curriculum in Malaysia is also undergoing a strengthened and improved transformation process known as the Primary School Curriculum which was implemented in 2011. The curriculum emphasizes from knowledge based curriculum to standard based curriculum. The Secondary School Standard Curriculum is implemented in stages beginning with Year 4 using the Curriculum and Assessment Standard Document (BPPM PJK, 2019). The Primary Education of Physical Education and Health Education curriculum is also undergoing refinement and review.

\section{Statement of Problem}

In the latest developments of the education world, each subject has its own issues and challenges, including the PEH subjects. Students are found to be less interested in physical activity because they think that Physical Education subjects have no academic value and unhealthy. Such a reason has been used by students to avoid engaging in any of the activities related to PEH in schools. Some of students who are not involved in sports activities as they focus on outstanding achievement in the examination (Salleh, 2018 ). Previous studies also have shown that parents consider Physical Education activities to be a waste of time for their children, and feel that the implementation of the PEH directly has nothing to do with the UPSR exams (Ali, et.al, 2014). The emphasis on parents is more on the academic side and less on the response (Salleh, 2018 ). The study by Syed Ali (et al., 2014) found that $80 \%$ of parents agree that Physical Education is a waste of time, does not guarantee the future and does not help in the examination. So, they concider that the subject is not really important.

The subject also faces a significant drop in interest rates in the pursuit of exams. This is particularly troubling when Malaysians themselves do not care about the importance of Physical Education subjects because they are not subject to examination and bring merit to the school's scoring system (Husain, 2014). Aside from being a subject that has no academic value, Physical Education subjects are found to be less interested, boring and exhausting by the students. Husain and Ab. Hadi (in Husain, 2014) also found that $35.4 \%$ of students' perceptions stated that Physical Education subjects were sometimes boring and exhausting. In addition, the study also showed that $18.2 \%$ of students were not interested in the curriculum of the PEH because among others, it was due to the poor teaching of teachers. Wee, Khor and Jamatul (2004) found that only $6.2 \%$ of primary school who teach PEH, are majors in PEH. Therefore, 'non-field' teaching seems to be the norm, encompassing not only inadequate teaching but non-teaching scenarios. It worsens by the lack of teaching time for a teacher is sometimes filled with PEH subjects, because administrators feel that all teachers can teach this subject. This is supported by Husain (2014) teaching that the PEH subject cannot be effectively implemented due to time constraints, lack of equipment, inadequate facilities and inadequate teachers or inexperienced teachers teaching PJK subjects. Therefore, the teaching and learning methodology should be adapted to the needs of the 21st century to make students more interested in learning subject and will not be a subject left behind.

\section{Walking Digital Gallery}

Cooperative and collaborative learning strategies are widely used in the teaching and learning process. Student-centered learning activities encourage active participation of students in various 
types and forms of group activities. Among them are the 'Think pair share'; 'Think pair square'; 'Gallery walk'; 'Round table'; 'Round robin'; 'Brainstroming'; and more (BPPM PJK, 2019).

Gallery Walk is one of the most exciting 21st century learning activities to take place. Gallery Walk is a discussion technique that allows students to work in small groups. They can share ideas and answer meaningful questions, scenarios or texts. It also benefits students where students can share ideas and be exposed to other people's ideas, speak, listen, consult, and build consensus among them. Gallery Walk is also referred to as a method that gives students the opportunity to move actively throughout the learning session compared to the regular or traditional learning process. In addition, it can also involve the use of technological equipment such as mobile phones and gallery which will showcase pictures, graphics, sentences, posters of various sizes and stations for activities to be carried out (Mccafferty \& Beaudry, 2017). Therefore, based on privileges and advantages of Gallery Walk, with addition in using digital equipments such as computers, tablets, smart phones, software, digital video, digital games, websites including social media, mp3 and e books (Cambridge Dictionary, 2017) will be implemented in the model. Therefore, this model is known as the Walking Digital Gallery (WDG).

\section{Application of Interpretive Structural Modeling (ISM)}

According to Warfield (1976), Interpretive Structural Modeling (ISM) is a technique that specifically designed to support the human brain in managing information and ideas in a clear structure through a targeted problem perspective. ISM is also a computer-based teaching and learning process that enables individuals and groups to develop a model or map of the relationships between elements involved in a given issue based on experience and expert knowledge. In other words, this technique is a free context, regardless of the content of the situation, allowing individuals or groups to collaboratively make decisions if the contextual and contextual elements of the relationship are identified (Abdullah \& Siraj, 2014). In addition, ISM is also referred to as a management decisionmaking tool that links individuals or groups' ideas to facilitate a comprehensive understanding of complex situations by using the relationship map between many elements involved in complex decision situations.

In a way, ISM solves complex problems by allowing experts to focus on two ideas at a time. The ideas and relationships between them are discussed in the framework of the problem under investigation. The end result of the ISM Process is a visual relationship between ideas and information. This map will reveal the basic concepts of the problem that are important for experts to discuss, understand, and make the right decisions. 
INTERNATIONAL JOURNAL OF ACADEMIC RESEARCH IN BUSINESS AND SOCIAL SCIENCES Vol. 10, No. 7, July, 2020, E-ISSN: 2222-6990 @ 2020 HRMARS

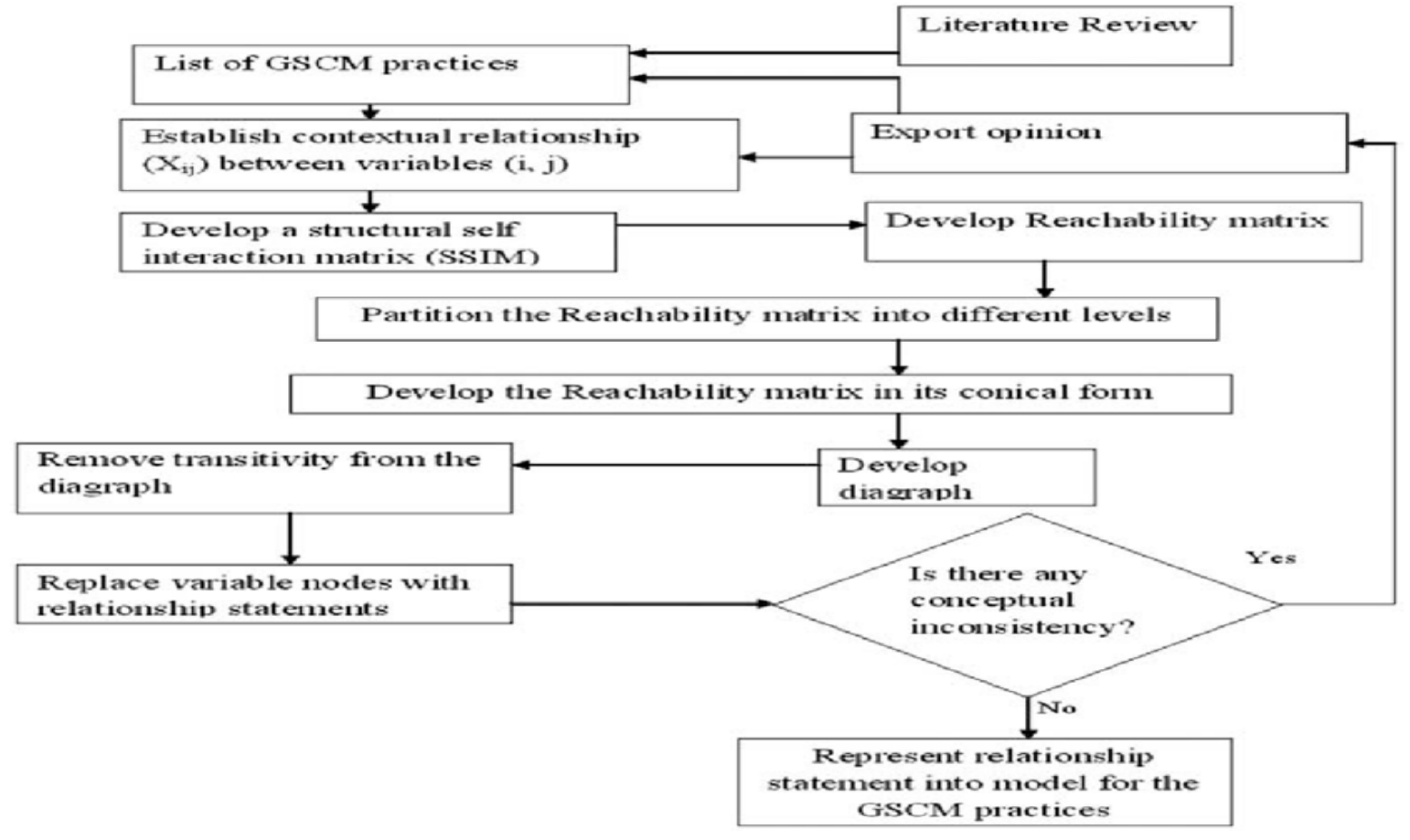

Figure 1: ISM Process (Kannan et.al, Resources, Conservation and Recycling 54, 28-36 , 2009)

\section{The Purpose of the Study}

The purpose of this study is to develop a Walking Digital Gallery curriculum model for PEH subject.

\section{Study Questions:}

This study attempts to answer the following research questions:

1. What is the ideal elements for the Walking Digital Gallery model for PEH primary school subjects?

2. What is the design of the Walking Digital Gallery for PEH primary school subjects?

\section{Research Methodology}

In the context of this study, ISM is used to help a line of experts reach consensus in formulating the relationships between elements within the Walking Digital Gallery model. The following are the steps or stages in the ISM procedure (Janes, 1988) that will form the basis for the development of the Walking Digital Gallery for PEH primary school subjects:

Step / Stage Description

1) Identify the issue to be studied

This stage is intended to identify issues or elements to explore using ISM. The first step to do is to make the Nominal Group Technique (NGT) to identify issues and problems within a workshop to facilitate brainstorming ideas. 8 selected experts were choosen to complete the task in NGT and also ISM procedure. The experts comprises of people with knowledge and experience in pedagogy, curriculum, $\mathrm{PEH}$, 
and also in educational technology. This workaround will determine the agreed upon elements that experts need to outline in order to understand the relationships between those elements.

2) Decide and define contextual and phrase relationships
This stage is to determine the shape of the elements to be generated. These include relationship phrases and contextual phrases needed in ISM.

3) Develop a structural self-interaction
matrix (SSIM)
3) Develop
matrix (SSIM)

4) Generating model
Concept Star software was used In this stage. The experts will vote on the relationship of the elements that already installed in the software. The voting process will continue until all elements have been installed and a model is installed.

A model generation is performed once all the elements are installed and selected. The ISM software itself will complement the mathematical calculation process including the Structural Self-Interaction Matrix (SSIM) as well as the Initial Reachabilty Matrix for ISM software users.

5) Display ISM model At this stage, the model that has been developed will be presented to the experts for review and modification if needed

The final model will be presented to the 6) Discuss the structure and amend it if necessary process has been completed

\section{Table 1: Steps in ISM procedure}

\section{Findings}

1) In the first stage of ISM

At the beginning of the NGT session, 25 elements of the activity were presented to the experts for evaluation. As a result of discussion and analysis by experts, there are some elements that need to be removed. The experts then agreed to accept 21 elements for the model. This answers the first research question, what are the elements of the Digital Travel Adventure model that fit. Table 2 shows the expert consensus on the 21 agreed elements. 
INTERNATIONAL JOURNAL OF ACADEMIC RESEARCH IN BUSINESS AND SOCIAL SCIENCES Vol. 10, No. 7, July, 2020, E-ISSN: 2222-6990 @ 2020 HRMARS

Table 2: Findings of the Walking Digital Gallery PEH Model Elements

\begin{tabular}{|c|c|c|c|c|}
\hline RANK & ELEMENT & SCORE & $\%$ & RATING \\
\hline 1 & Create an interactive learning environment & 53 & 94 & ACCEPTED \\
\hline 2 & Apply planning skills to students & 52 & 94 & ACCEPTED \\
\hline 3 & $\begin{array}{l}\text { Instruct students to form their own small } \\
\text { groups }\end{array}$ & 52 & 94 & ACCEPTED \\
\hline 4 & Provides presentation guidelines & 52 & 94 & ACCEPTED \\
\hline 5 & $\begin{array}{l}\text { Implement communication skills among } \\
\text { students }\end{array}$ & 52 & 94 & ACCEPTED \\
\hline 6 & $\begin{array}{l}\text { To guide students' existing knowledge of the } \\
\text { subject of PEH }\end{array}$ & 51 & 91 & ACCEPTED \\
\hline 7 & Guide students in preparing the presentation & 51 & 91 & ACCEPTED \\
\hline 8 & $\begin{array}{l}\text { Encourage students to express themselves } \\
\text { using digital tools }\end{array}$ & 51 & 91 & ACCEPTED \\
\hline 9 & Apply teamwork skills & 51 & 91 & ACCEPTED \\
\hline 10 & Apply decision-making skills & 51 & 91 & ACCEPTED \\
\hline 11 & $\begin{array}{l}\text { Guide students in designing the storyboard of } \\
\text { the Walking Digital Gallery PEH }\end{array}$ & 51 & 91 & ACCEPTED \\
\hline 12 & Applying rationalization skills & 51 & 91 & ACCEPTED \\
\hline 13 & $\begin{array}{l}\text { Helps students upload their Walking Digital } \\
\text { Gallery PEH assignments through social } \\
\text { media platforms }\end{array}$ & 50 & 89 & ACCEPTED \\
\hline 14 & $\begin{array}{l}\text { Apply the skills of making conclusions in each } \\
\text { of the activities of the Walking Digital Gallery } \\
\text { PEH }\end{array}$ & 50 & 89 & ACCEPTED \\
\hline 15 & $\begin{array}{l}\text { Implementing research skills in Walking } \\
\text { Digital Gallery PEH }\end{array}$ & 50 & 89 & ACCEPTED \\
\hline 16 & Apply digital usage skills & 50 & 89 & ACCEPTED \\
\hline 17 & Provides conclusion via e-RPH & 50 & 89 & ACCEPTED \\
\hline 18 & $\begin{array}{l}\text { Guiding students to come up with the idea of } \\
\text { the Walking Digital Gallery PEH assignment }\end{array}$ & 49 & 87 & ACCEPTED \\
\hline 19 & $\begin{array}{l}\text { Help students choose the E-Learning app for } \\
\text { Walking Digital Gallery PEH }\end{array}$ & 49 & 87 & ACCEPTED \\
\hline
\end{tabular}


INTERNATIONAL JOURNAL OF ACADEMIC RESEARCH IN BUSINESS AND SOCIAL SCIENCES Vol. 10, No. 7, July, 2020, E-ISSN: 2222-6990 @ 2020 HRMARS

\begin{tabular}{lllll}
\hline 20 & $\begin{array}{l}\text { Provides digital facilities for PJK Walking } \\
\text { Digital Gallery PEH }\end{array}$ & 48 & 85 & ACCEPTED \\
\hline 21 & $\begin{array}{l}\text { Guide students using search engine } \\
\text { applications with digital tools }\end{array}$ & 48 & 85 & ACCEPTED \\
\hline
\end{tabular}

* Percentage acceptance $\leq 70$ percent

Findings Table 2 shows all 21 elements that have been accepted for inclusion in the Walking Digital Gallery model of PEH. The percentage of elements evaluated is at the appropriate level for use. According to Dobbie et al. (2004) the condition of acceptance of an element is that the percentage of votes must exceed $70 \%$. Therefore, it is clear that all elements are acceptable and suitable for use as model elements.

2) The ISM's second-level analysis of the type of ISM that will be built determines the context and contextual phrases it wants to structure in the ISM. Findings of the phrases that are relevant to the context of the study are as follows:

Relationship Phrases: 'need to be implemented before...'

3) Third and fourth level insights: This stage is an important step in developing a model. The findings of this step answer the second question of the study, which is based on the expert consensus, what is the design of the Walking Digital Gallery PEH. At this stage the compiled elements will be presented using Concept Star software. The expert will vote until all elements have been installed and a model is built. A schematic view of the model can be seen in figure 2 below: 
INTERNATIONAL JOURNAL OF ACADEMIC RESEARCH IN BUSINESS AND SOCIAL SCIENCES Vol. 10, No. 7, July, 2020, E-ISSN: 2222-6990 @ 2020 HRMARS

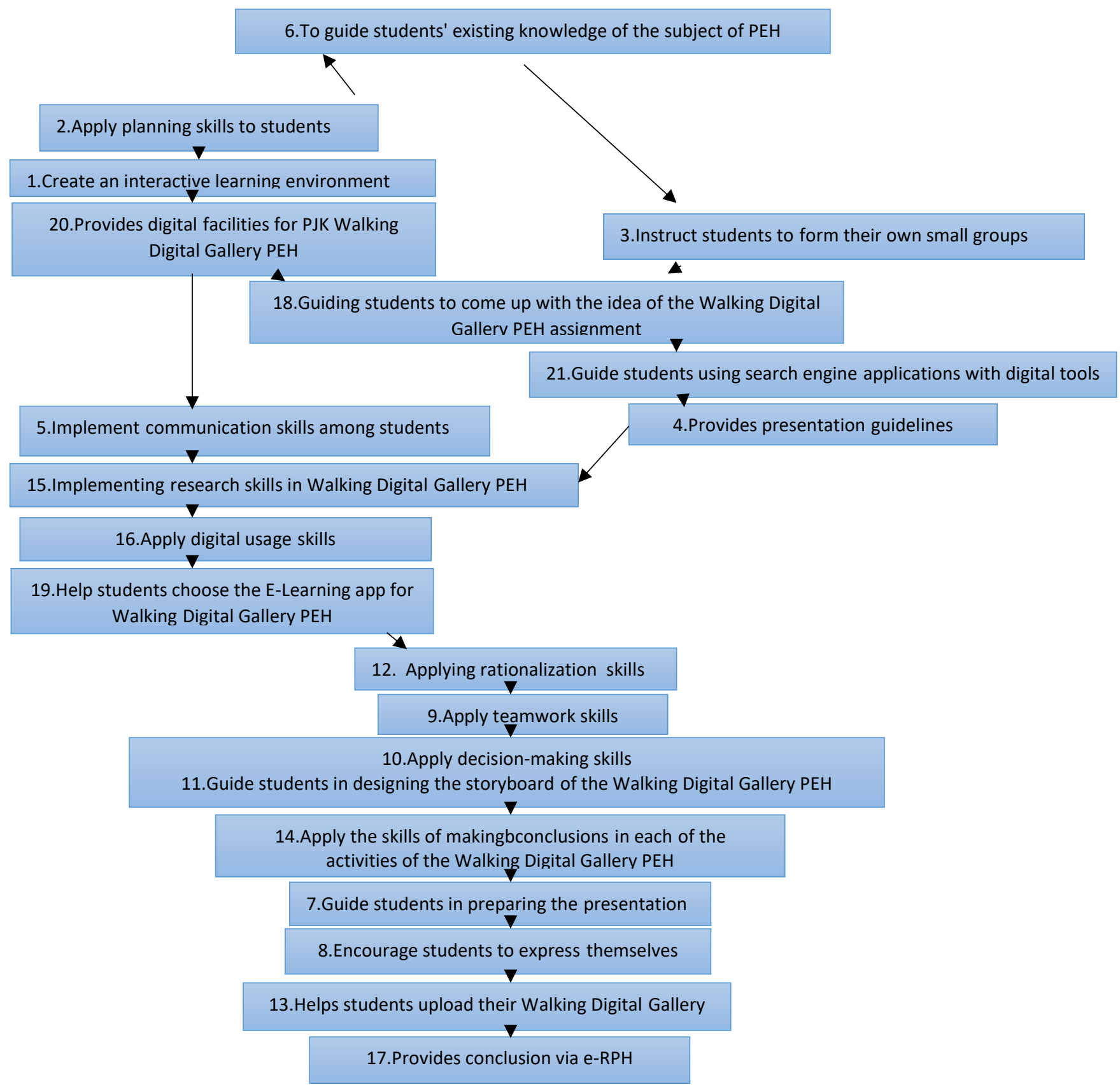

Figure 2: Walking Digital Gallery Physical Education and Health Model

4) The final findings of Stages 5 and 6, the discussion and the structural amendments show that the line of experts has agreed to maintain without making any amendments to the design of the model. They also has confirmed the resulting model. Based on Figure 2, the finding shows that element 6 'To guide students' existing knowledge of the subject of $\mathrm{PEH}^{\prime}$ is in the highest position before the other elements. In other words, element 6 has a higher driving power than any other element. According to Abdul Rahman (2014), driving power is the power that drives an activity or other element to achieve a goal by itself. Thus element 6 influences the other elements in achieving the goals of the model. 
INTERNATIONAL JOURNAL OF ACADEMIC RESEARCH IN BUSINESS AND SOCIAL SCIENCES

Vol. 10, No. 7, July, 2020, E-ISSN: 2222-6990 @ 2020 HRMARS

\section{Discussion}

To answer the first question of the study - all the elements of the Walking Digital Gallery for PEH model were created based on expert opinion and discussion through the NGT technique. It has been done in the first stage in the ISM procedure. The findings show that all 21 elements are accepted and included in the model as shown in Table 2. The most important element is element 6 'to guide students existing knowledge of the subject of PEH'. Meanwhile, the element 17 'Provides conclusion via E-RPH' element is in the last position as shown in Figure 2.

To answer the second question of the study - the findings of the study can be seen in Figure 2. The model that has been developed is in line with Bloom's Taxonomy theory whereby the stages of human learning must be initiated by knowledge and followed by other stages with knowledge and followed by other stages (Anderson, Krathwohl \& Bloom, 2001). With the help of the Concept Star ISM software, each element is matched to each other using a hierarchical method based on pairing techniques until all of these elements are paired and voted on by experts, thus building the PEH model.

\section{Conclusion}

Based on the findings of this study, the model is comprised of 21 key elements that are a combination of expert interviews, extensive reading of the literature review and expert consensus views through the phases. As such, this model is expected to assist teachers in particular in conducting more interactive learning and facilitating sessions and may benefit various stakeholders in the field of general education. The results of the expert agreement also clearly indicate the role of the teacher only as facilitator and motivator. The integration of information technology and media makes it compatible with pedagogy as well as teaching techniques that will facilitate and support students to succeed in 21st century learning (Rosdin \& Ali, 2019). For further study, the researcher proposes to develop specific modules according to the model.

\section{References}

Abdul Rahman, M. N. (2014). Pembangunan Model Home Schooling Berasaskan Nilai Dan Amalan Masyarakat Bagi Kanak Kanak Orang Asli, Fakulti Pendidikan, Universiti Malaya.

Abdullah, M. R. T., \& Siraj, S. (2014) Aplikasi Kaedah Interpretive Structural Modeling Untuk Pembinaan Model Implementasi M-Pembelajaran, Latihan Perguruan Institut Pengajian Siswazah, Universiti Malaya

Anderson, L. W., Krathwohl, D. R., Airasian, P. W., Cruikshank, K. A., Mayer, R. E.,

Pintrich, P. R., Raths, J., \& Wittrock, M. C. (2001). A Taxonomy for Learning, Teaching, and Assessing: A Revision of Bloom's Taxonomy of Educational Objectives. New York: Longman.

Buku Panduan Pengurusan Matapelajaran. (2019). Pendidikan Jasmani dan Kesihatan Sekolah Rendah Sekolah Menengah, Jemaah Nazir, Kementerian Pendidikan Malaysia

Cambridge dictionary. (2013). Cambridge University Press, Cambridge UK

Dobbie, A., Rhodes, M., Tysinger, J. W., \& Freeman, J. (2004). Using a Modified Nominal Group Technique as a Curriculum Evaluation Tool. Family Medicine, 36 (6), 402- 406.

Husain, M. Z. (2016), Pembangunan model konsep standard pengajaran guru pendidikan jasmani berorientasikan amalan dan kluster perwatakan guru, Fakulti 
INTERNATIONAL JOURNAL OF ACADEMIC RESEARCH IN BUSINESS AND SOCIAL SCIENCES

Vol. 10, No. 7, July, 2020, E-ISSN: 2222-6990 @ 2020 HRMARS

Pendidikan Teknikal dan Vokasional, Universiti Tun Hussein Onn Malaysia.

Janes, F. R. (1988). Interpretive structural modeling: A methodology for structuring complex issues. Transactions of the Institute of Measurement and Control, 10(3), 145-154.

Kannan, G., Pokharel, S., Sasi Kumar, P. (2009). A hybrid approach using ISM and fuzzy TOPSIS for the selection of reverse logistics provider. Resources, Conservation and Recycling 54, 28-36

Mccafferty, A. S., \& Beaudry, J. (2017). The gallery walk educators step up to build assessment literacy the learning professional, 38(6). Retreive from www.learningforward.org

Rusdin, M. N. \& Ali, S.R. (2019), Amalan dan Cabaran Pelaksanaan Pembelajaran Abad 21, Proceeding of International Conference On electronic civilization and technology management, 23-24 november 2019, Research and Malay Civilization (INSPIRE) Universiti Sultan Zainal Abidin eISBN978-967-2231-26-4

Salleh, Abd.Aziz. (2018).Isu-isu pelaksanaan pendidikan jasmani dan kesihatan di sekolah Academia.edu/9153957/isu-

isu_pelaksanaan_pendidikan_jasmani_dan_kesihatan_di_sekolah, dimuatturun pada 5 Mei 2018

Ali, S. K., Zahidi, M. A., Sukor, R., Ab. Samad, \& Wee, A. S. S. L. (2014), Faktor Kekangan Ibu Bapa dan Persekitaran Sekolah Dalam Pelaksanaan Pengajaran Pendidikan Jasmani Di Sekolah Rendah, JuKu: Jurnal Kurikulum \& Pengajaran Asia Pasifik - April 2014, Bil. 2 Isu 2(1-15)

Veloo, A., Md Ali, R. (2016). Physical Education Teachers Challenges in Implementing School Based Assessment, International Review of Management and Marketing ISSN: 2146-4405 available at http: www.econjournals.com International Review of Management and Marketing, 2016, 6(S8) 48-53.

Warfield, J. N. (1976). Societal systems: planning, policy and complexity, New York USA : John Wiley \& Sons, INC.

Wee, E. H., Khor, P. W., \& Jamatul, S. (2004). Needs analysis of Physical Education Teachers in Malaysian Primary Schools. Universiti Internal Grant: Universiti of Teknologi MARA. 